\title{
Manajemen Mutu Outcome Penyelenggaraan Ibadah Haji
}

\author{
Cecep Abdu Rohman*, Aep Kusnawan, Yuliani \\ Jurusan Manajemen Dakwah, UIN Sunan Gunung Djati, Bandung \\ *Email : cecep.abdu@student.uinsgd.ac.id
}

\begin{abstract}
ABSTRAK
Penelitian ini menggambarkan mutu kepuasan pelayanan ibadah haji; untuk memperoleh gambaran mutu kemabruran jemaah haji; dan dampak alumni jemaah haji di tengah masyarakat setelah melaksanakan ibadah haji yang diselenggarakan oleh kantor wilayah Kementerian agama Provinsi Jawa Barat. Metode penelitian ini menggunakan metode deskriptif, jenis data yang di gunakan adalah kulitatif, sumber data yang digunakan adalah data primer dan juga sekunder adapun teknik pengumpulan data yang digunakan dalam penelitian adalah observasi, wawancara, dan studi dokumentasi. Adapun analisis data dilakukan melalui penafsiran logika yang dihubungkan dengan konteks Manajemen Dakwah. Hasil penelitian menunjukkan bahwa: Pertama, Kanwil Kemenag Jabar bidang haji dan Umrah dalam meraih kesuksesannya memperhatikan tahapantahapan, yaitu: Perencanaan; Pengorganisasian; Pelaksanaan pelayanan pada jemaah haji. Kedua, Mutu kemabruran jemaah haji didasarkan pada perubahan sikap jemaah haji yang lebih baik. Ketiga, Dampak alumni haji ditengah masyarkat. Secara umum penelitian ini dapat disimpulkan bahwa manajemen mutu suatu penyelenggara ibadah haji menghasilkan outcome dari alumni jemaah haji yang mabrur dan memiliki manfaat yang fositif ditengah masyarakat.
\end{abstract}

Kata Kunci : Manajemen; Mutu; Penyelenggaraan Ibadah Haji

\section{ABSTRACT}

This study describes the quality of satisfaction of Haij services; to obtain a picture of the quality of the pilgrims' journey; and the impact of alumni of pilgrims in the community after performing the pilgrimage held by the office of the Ministry of Religious Affairs of West Java Province. This research method using descriptive method, the type of data that is used is leather, the data source used is primary data and also the secondary data collection techniques used in the research are observation, interview, and documentation study. The data analysis is done through the interpretation of logic that is connected with the context of Da'wah Management. The results showed that: First, Kanwil Kemenag Jabar field of pilgrimage and Umrah in achieving its success attention to the stages, namely: Planning; Organizing; Implementation of service to pilgrims. Second, the quality of the pilgrims' pilgrimage is based on a better attitude of pilgrims. Third, the impact of Haij alumni in the community. In general, this study can be concluded that the quality management of a pilgrimage provider produces outcomes from alumni pilgrims who 
Cecep Abdu Rohman, Aep Kusnawan, Yuliani

mabrur and has a fossil benefits in the community.

Keywords: Management; Quality; Organizing Hajj.

\section{PENDAHULUAN}

Ibadah haji merupakan perjalanan religius yang melibatkan segala aspek ibadah baik secara jasmani maupun rohani. Dalam pelaksanaan ibadah haji terdapat nilai edukasi yang sangat kental. Nilai-nilai ini dapat membentuk pemahaman, penghayatan, dan motivasi untuk menunaikan tugas yang diberikan oleh Allah swt kepada manusia sebagai khalifah di muka bumi. Salah satu tanda diterimanya amal seseorang di sisi Allah adalah diberikan taufik untuk melakukan kebaikan lagi setelah amalan tersebut. Bertaubat setelah haji, berubah menjadi lebih baik, memiliki hati yang lebih lembut dan bersih, ilmu dan amal yang lebih mantap dan benar, kemudian istiqamah di atas kebaikan merupakan beberapa tanda seseorang telah menjadi haji mabrur. Orang yang hajinya mabrur menjadikan ibadah haji sebagai titik tolak untuk membuka lembaran baru dalam menggapai ridho Allah.

Karena ibadah haji merupakan ritual ibadah yang sangat istimewa dan tidak semua manusia dapat menunaikannya, hanya manusia pilihan dan mampu baik dalam segi fisik, harta dan tekad serta niat yang kuat untuk melaksanakannya. Maka tentu dari pada itu, karena ibadah haji merupakan ibadah yang istimewa dan yang menjalankannya manusia pilihan Allah, maka harus ditunjang juga dengan manajemen mutu dalam penyelenggaraan ibadah haji tersebut. Sehingga nanti akan mengahasilkan outcome dari para Jemaah haji yang memiliki kepribadian yang lebih baik, terutama memanfaatkan kemabruran ibadah haji untuk ikut dalam berkontribusi dalam membangun negeri.

Indonesia merupakan negara yang memiliki populasi umat muslim terbanyak di dunia, maka sangat jelas, Jemaah yang ingin menunaikan ibadah haji di Indonesia juga terbilang sangat banyak. Terutama pada tahun 2017 ini, jumlah haji di indoneisa meningkat, yaitu sebanyak 221.000 orang (KMA, 2017: 75). Tentu dari jumlah tersebut akan menghasilkan outcome yang banyak dari para alumni haji yang telah usai melaksanakan ibadah hajinya.

Keputusan Menteri Agama Republik Indonesia Nomor 75 Tahun 2017 tentang Penetapan Kuota Haji Tahun 1438H/2017M. Pemerintah khususnya Mentri Agama telah menetapkan dan membagi kuota nasional 2017 menjadi kuota masing-masing provinsi. Kuota nasional ditetapkan oleh Menteri Agama sebanyak 221.000 (dua ratus dua puluh ribu) orang. Lalu kuota nasional itu dibagi lagi ke dalam kuota haji regular sebanyak 204.000 (dua ratus empat ribu) orang dan kuota haji khusus sebanyak 17.000 (tujuh belas ribu) orang. (KMA, 2017: 75)

Dari beberapa provinsi yang ada diseluruh Indonesia, provinsi jawa barat yang memiliki kuota terbanyak yaitu dibagi kedalam dua bagian. Pertama kuota regular masing-masing provinsi, kuota terbesar adalah Provinsi Jawa Barat yaitu sebanyak 38.852 orang, sedangkan kuota terkecil adalah Provinsi Nusa Tenggara Timur yaitu sebanyak 670 orang. Kedua rincian kuota haji khusus, dengan jumlah Jemaah 15.663 dan petugas dari unsur PIHK 756 orang, pembimbing ibadah 378 
orang, dokter 189 orang, dan pengurus asosiasi 14 orang. (KMA, 2017: 75)

Provinsi Jawa Barat memiliki potensi alumni Jemaah haji yang sangat banyak dibandingkan dengan 32 provinsi lainnya. Dengan begitu para alumni Jemaah haji provinsi ini lebih banyak peluang untuk berkontribusi untuk negeri. Dilihat dari beberapa institusi yang ada di provinsi jawa barat, kebanyakan diatur dan dikendalikan oleh para alumni Jemaah haji. Misalkan, presiden Republik Indonesia pada masa sekarang yaitu Joko Widodo, beliau adalah alumni haji pada tahun 2003. Di Jawa Barat sendiri memiliki sosok pemimpin seorang gubernur yaitu Ahmad Heryawan, beliau juga merupakan alumni haji yang telah berkontribusi untuk kemajuan negeri.

Jumlah Kantor Wilayah Kementerian Agama (Kanwil) di Indonesia mengikuti jumlah provinsi, yaitu sebanyak 33 (tiga puluh tiga) buah. Kanwil Kemenag Provinsi D.I Aceh, Kanwil Kemenag Provinsi Sumatera Utara, Kanwil Kemenag Provinsi Sumatera Barat, Kanwil Kemenag Provinsi Jambi, Kanwil Kemenag Provinsi Riau, Kanwil Kemenag Provinsi Kepualauan Riau, Kanwil Kemenag Provinsi Sumatera Selatan, Kanwil Kemenag Provinsi Bengkulu, Kanwil Kemenag Provinsi Bangka Belitung, Kanwil Kemenag Provinsi Lampung, Kanwil Kemenag Provinsi Banten, Kanwil Kemenag Provinsi DKI Jakarta, Kanwil Kemenag Provinsi Jawa Barat, Kanwil Kemenag Provinsi Jawa Tengah, Kanwil Kemenag Provinsi Yogyakarta, Kanwil Kemenag Provinsi Jawa Timur, Kanwil Kemenag Provinsi Bali, Kanwil Kemenag Provinsi Nusa Tenggara Barat, Kanwil Kemenag Provinsi Nusa Tenggara Timur, Kanwil Kemenag Provinsi Kalimantan Barat, Kanwil Kemenag Provinsi Kalimantan Tengah, Kanwil Kemenag Provinsi Kalimantan Selatan, Kanwil Kemenag Provinsi Kalimantan Timur, Kanwil Kemenag Provinsi Gorontalo, Kanwil Kemenag Provinsi Sulawesi Utara, Kanwil Kemenag Provinsi Sulawesi Tengah, Kanwil Kemenag Provinsi Sulawesi Tenggara, Kanwil Kemenag Provinsi Sulawesi Selatan, Kanwil Kemenag Provinsi Sulawesi Barat, Kanwil Kemenag Provinsi Maluku, Kanwil Kemenag Provinsi Maluku Utara, Kanwil Kemenag Provinsi Papua, Kanwil Kemenag Provinsi Papua Barat. (KMA, 2017: 75)

Kantor Wilayah Kementerian Agama bagian Haji dan Umroh Provinsi Jawa Barat merupakan salah satu Kanwil Kemenag di Kementerian Agama. Fungsi dari Kanwil Kemenag Provinsi jawa barat bidang haji dan umroh yakni melaksanakan pelayanan, bimbingan, pembinaan, dan pengelolaan sistem informasi di bidang penyelenggaraan haji dan umrah berdasarkan kebijakan teknis yang ditetapkan oleh Kepala Kantor Wilayah Kementerian Agama. (Pasal 377 PMA No. 13 Tahun 2012).

Terkait dengan paparan diatas, pada tataran praktisnya ada beberapa hal yang menarik untuk dipahami lebih lanjut, yaitu sehubungan dari hasil temuan dilapangan oleh penulis dan juga dari hasil wawancara dengan salah satu staff Kanwil Kementerian Agama Provinsi Jawa Barat dan beberapa masyarakat. Hal tersebut berkaitan dengan Jemaah haji yang sudah menjadi alumni atau sudah melaksanakan ibadah haji. Diantara permasalahan yang diitemukan diantaranya 
adalah:

Pertama, bahwa setiap penyelenggara ibadah haji pada umumnya sudah merumuskan kebijakan atau program kerja. Hal itu berguna sebagai arah penyelenggaraan ibadah haji namun pelaksanaanya belum konsekuen, penyelenggara hanya mencukupkan diri untuk sesuai pada persyaratan-persyaratan dan pada akhirnya mendapat pengakuan.

Kedua, masih kurangnya Jemaah haji yang memberikan kontribusi kemabruran ibadah hajinya untuk membangun negeri.

Ketiga, meningkatnya outcome dari Jemaah haji yang berkualitas, agar dapat memberikan kontribusi kemabruran ibadah hajinya untuk membangun negeri.

Kanwil Kemenag Provinsi Jawa Barat, harus bisa memperankan dan memfungsikan tidak hanya sebagai praktisi penyelenggara ibadah haji, tetapi harus bisa mengontrol dan mengelola para alumni Jemaah haji supaya kualitas dan mutu dari hasil ibadah yang diproleh oleh para jemaah bisa dimanfaatkan untuk kemaslahatan pembangunan negeri.

Berdasarkan data di atas, peneliti melihat bahwa umat muslim yang melaksanakan ibadah haji merupakan manusia pilihan. Proses penyelenggaraan ibadah haji dengan mengoptimalkan manajemen mutu akan menghasilkan outcome dari Jemaah yang mengkontribusikan kualitas dirinya untuk membangun negeri. Maka dari itu, penulis tertarik untuk meneliti tentang Manajemen Mutu Outcome Penyelenggaraan Ibadah Haji. Adapun lokasi penelitiannya di Kementerian Agama Provinsi Jawa Barat, di bidang Haji dan Umroh.

\section{LANDASAN TEORITIS}

Teori yang akan dijadikan landasan dalam penelitian ini adalah teori manajemen, manajemen mutu, outcome maping dan pelaksanaan (actuating). Manajemen merupakan alat untuk mencapai tujuan yang diinginkan. Manajemen yang baik akan memudahkan terwujudnya tujuan perusahaan, karyawan, dan masyarakat. Dengan manajemen, daya guna dan hasil guna unsur-unsur manajemen akan dapat ditingkatkan. Adapun unsur-unsur manajemen itu terdiri dari: man, money, methode, machines, materials, dan market, disingkat 6M. Manajemen berasal dari kata to manage yang artinya mengatur, timbul pertanyaan tentang: apa yang diatur, apa tujuannya diatur, mengapa harus diatur, siapa yang mengatur, dan bagaimana mengaturnya. (Hasibuan 2011: 1)

Dengan demikian, dalam penelitian ini dapat dipahami bahwa manajemen merupakan suatu rangkaian kegiatan mulai dari perencanaan, pengorganisasian, pengarahan, pengendalian serta pengawasan dengan memanfaatkan sumber daya manusia serta sumber-sumber daya lainnya untuk mencapai suatu tujuan organisasi yang telah ditentukan.

Fungsi-fungsi manajemen adalah elemen-elemen dasar yang selalu ada dan melekat di dalam proses manajemen yang akan dijadikan acuan oleh manajer dalam melaksanakan kegiatan untuk mencapai tujuan. Namun terdapat perbedaan pandangan mengenai fungsi-fungsi manajemen oleh beberapa ahli. Menurut 
George R. Terry (Hasibuan, 2011: 38) fungsi-fungsi manajemen meliputi Perencanaan (planning), Pengorganisasian (organizing), Pengarahan (actuating) dan Pengendalian (controlling). Fungsi-fungsi manajemen meliputi Perencanaan (planning), Pengorganisasian (organizing), Pengarahan (commanding), Pengkoordinasian (coordinating), Pengendalian (controlling). Sedangkan menurut Ricki W. Griffin (Safroni, 2012: 47), fungsi-fungsi manajemen meliputi Perencanaan dan Pengambilan Keputusan (planning and decision making), pengorganisasian (organizing), Pengarahan (leading) serta pengendalian (controlling). (Safroni, 2012: 47)

Dengan demikian, dari perbandingan fungsi-fungsi manajemen di atas, dapat dipahami bahwa semua manajemen diawali dengan perencanaan (Planning) karena perencanaan yang akan menentukan tindakan apa yang harus dilakukan selanjutnya. Setelah perencanaan adalah pengorganisasian (organizing). Hampir semua ahli menempatkan pengorganisasian diposisi kedua setelah perencanaan. Pengorganisasian merupakan pembagian kerja dan sangat berkaitan erat dengan fungsi perencanaan karena pengorganisasian pun harus direncanakan. Selanjutnya setelah menerapkan fungsi perencanaan dan pengorganisasian adalah menerapkan fungsi pengarahan yang diartikan dalam kata yang berbeda-beda seperti actuating, leading, dan commanding, tetapi mempunyai tujuan yang sama yaitu mengarahkan semua karyawan agar mau bekerjasama dan bekerja efektif untuk mencapai tujuan organisasi. Tetapi juga ada penambahan fungsi pengkoordinasian (coordinating) setelah fungsi pengarahan. Fungsi pengkoordinasian untuk mengatur karyawan agar dapat saling bekerjasama sehingga terhindar dari kekacauan, percekcokan dan kekosongan pekerjaan. Selanjutnya fungsi terakhir dalam proses manajemen adalah pengendalian (controlling).

Menurut kamus besar Bahasa Indonesia (KBBI), mutu adalah ukuran, derajat, atau taraf tentang baik buruknya suatu produk barang atau jasa. Mutu bukanlah harga atau biaya, tetapi kesamaan terhadap standar yang telah ditetapkan. Suatu barang atau jasa dikatakan bermutu apabila barang atau jasa tersebut mempunyai derajat kesempurnaan yang sesuai dengan standar yang ada. Dalam istilah lain dapat dikemukakan bahwa mutu adalah perpaduan sifat- sifat dan karakteristik produk atau jasa yang dapat memenuhi kebutuhan pemakai atau pelanggan.

Manajemen Mutu merupakan sistem yang memperbaiki kualitas secara terus menerus. Davis dalam (Yamit 2005: 22) membuat definisi kualitas atau mutu yang lebih luas cakupannya yaitu kualitas merupakan suatu kondisi dinamis yang berhubungan dengan produk, jasa, manusia, proses dan lingkungan yang memenuhi atau melebihi harapan. Pendekatan yang dikemukakan Davis menegaskan bahwa kualitas bukan hanya menekankan pada aspek akhir yaitu produk dan jasa tetapi juga menyangkut kualitas manusia, kualitas proses dan kualitas lingkungan. Sangatlah mustahil menghasilkan produk dan jasa yang berkualitas tanpa melalui manusia dan produk yang berkualitas. Suatu produk/jasa dapat dikatakan berkualitas apabila dapat memenuhi harapan, keinginan serta kebutuhan pelanggan. Kualitas tidak hanya dilihat pada hasil akhirnya saja, tetapi 
Cecep Abdu Rohman, Aep Kusnawan, Yuliani

juga dilihat dari proses terbentuknya produk/jasa tersebut.

Dengan kata lain, melalui manajemen yang baik, kesalahan dalam organisasi bisa di minimalisir dan diantisipasi dari jauh-jauh hari. Dengan memperhatikan mutu, semua pekerjaan bisa dilakukan dengan maksimal dan memuaskan dari berbagai sudut.

Keuntungan pengendalian mutu menurut (Ishikawa 1992: 16) yaitu memungkinkan perusahaan untuk menemukan kesalahan atau kegagalan dalam proses produksi. Selain itu, desain produk dapat mengikuti keinginan pelanggan secara efisien sehingga produknya selalu dibuat sesuai pilihan pelanggan. Keuntungan yang didapat perusahaan karena menyediakan barang atau jasa yang berkualitas baik berasal dari pendapatan penjualan yang lebih tinggi dan biaya yang lebih rendah, gabungan keduanya menghasilkan profitabilitas dan pertumbuhan perusahaan (Ishikawa, 1992: 42).

TQM bertanggungjawab untuk mendeteksi hal-hal yang tidak sesuai dengan pengendalian mutu, maka dari itu pekerja lebih bertanggungjawab untuk pengendalian mutu dan menghentikan produksi ketika ada suatu masalah dalam produksi. Keuntungan yang didapat oleh perusahaan ketika menyediakan barang atau jasa yang berkualitas baik berasal dari pendapatan penjualan yang lebih tinggi dan biaya yang lebih rendah, gabungan keduanya dapat menghasilkan profitabilitas dan pertumbuhan perusahaan (Ishikawa, 1992: 16).

Outcome Maping merupakan kerangkan berpikir dalam manajemen program. Outcome Maping mengakui kompleksitas sistem sosial dan keterbatasan pengaruh intervensi program. Pendekatan ini berorientasi pada perubahan pelaku aktor, interaksi antaraktor, dan pemetaan perubahan tersebut. Outcome Maping fokus pada hasil yang sangat spesifik: perubahan prilaku, hubungan, kegiatan, atau tindakan orang-orang, kelompok dan organisasi yang bekerja langsung dalam program. Prubahan prilaku memiliki kontribusi yang sangat penting dalam pencapaian tujuan akhir program. (Deprez, 2010: 1-2)

Penyelenggaraan atau biasa disebut dengan pelaksanaan, dalam bahasa Inggris disebut dengan actuating merupakan salah satu dari empat fungsi manajemen yang kita kenal dengan istilah POAC (planning, organizing, actuating dan controlling). Pelaksanaan (actuating) merupakan tindak lanjut yang dilakukan oleh organisas yang telah memiliki perencanaan dan melakukan pengorganisasia yang terstruktur sesuai kebutuhan satuan kerja.l

Pelayanan dapat diartikan sebagai kepedulian kepada pelanggan-pelanggan dengan memberikan layanan terbaik untuk memfasilitasi kemudahan pemenuhan kebutuhan dan mewujudkan kepuasannya, agar mereka setia kepada perusahaan. Keberhasilan program Pelayanan tergantung pada penyelarasan kemampuan, sikap, penampilan, perhatian, tindakan, dan tanggung jawab dalam pelaksanaannya. (Arif, 2010:214)

Ibadah haji merupakan rukun Islam yang kelima yang merupakan salah satu kewajiban umat Islam dunia untuk menjalankannya bagi mereka yang mampu. Secara bahasa, kata haji berasal dari bahasa Arab, hajj yang berarti ziarah. Dalam 
hal ini adalah ziarah ke tempat-tempat yang diagungkan oleh agama Islam, yakni Baitullah Makkah dan Madinah, tepatnya adalah menziarahi ka'bah dengan syarat dan rukun tertentu (Ardani, 2008: 39).

\section{HASIL DAN PEMBAHASAN}

Penelitian ini dilakukan di Kantor Wilayah Kementerian Agama Provinsi Jawa Barat Bidang Haji dan Umroh yang beralamat di Jl. Jenderal Sudirman No. 644 BANDUNG-40183 Provinsi Jawa Barat. Pengambilan lokasi di daerah tersebut mengingat besarnya kemungkinan penelitian dapat dilaksanakan yaitu dengan melihat data-data yang dibutuhkan dalam penelitian ini tersedia dan untuk mengumpulkan data-data juga tidak terlalu sulit karena di Kantor Wilayah Kementerian Agama Provinsi Jawa Barat Bidang Haji dan Umroh sistem pengarsipannya tertata dengan rapi.

Di samping itu hubungan antara pihak penyusun dengan pihak Kanwil Provinsi Jawa Barat telah terjalin dengan baik. Kemudian dilihat dari pertimbangan kesesuaian dengan latar belakang akademik penyusun, penelitian ini tepat dilaksanakan mengingat ada korelasi antara penyusun yang sedang studi tentang manajemen dakwah dengan pengambilan judul dan objek penelitian tersebut.

Dilihat dari pertimbangan geografis, mudah dijangkau karena tempat tinggal penyusun tidak jauh dari lokasi penelitian sehingga dalam penelitian ini tidak memerlukan sarana dan prasarana yang lebih banyak.

Hasil penelitian ini menemukan tentang manajemen pelayanan jemaah haji di Kanwil Wilayah Kementerian Agama Provinsi Jawa Barat, mutu kemabruran ibadah haji Di Kanwil Kementerian Agama Provinsi Jawa Barat, dampak alumni jemaah haji di tengah masyarakat setelah melaksanakan ibadah haji yang diselenggarakan oleh Kanwil Wilayah Kementerian Agama Provinsi Jawa Barat

\section{Manajemen Pelayanan Jemaah Haji Di Kanwil Wilayah Kementerian Agama Provinsi Jawa Barat}

Tentang penyelenggaraan ibadah haji merupakan pedoman dalam menyelenggarakan ibadah haji menyangkut rangkaian kegiatan pengelolaan pelaksanaan pembinaan, pelayanan, dan perlindungan kepada jemaah calon haji. Pembinaan, pelayanan, dan perlindungan adalah tiga unsur yang menjadi pilar penyangga keberhasilan pemerintah dalam menyelenggarakan ibadah haji. (Choliq, 2011:22)

Berdasarkan hasil wawancara dengan staff Kanwil Kemenag Jabar Bidang Haji dan umroh, yaitu Amri (wawancara 5 Februari 2018), menyatakan bahwa lembaga pemerintah yang menjadi leading sector penyelenggara ibadah haji adalah Kementerian Agama. Kanwil Kementerian Agama bidang penyelenggara ibadah haji dan umrah Provinsi Jawa Barat sebagai leading sector dalam menyelenggarakan ibadah haji di Provinsi Jawa Barat, bertanggung jawab atas kesuksessan penyelenggaraan ibadah haji. Dalam rangka mencapai kesuksesan penyelengaraan 
ibadah haji maka diperlukan manajemen pelayanan di Kanwil Kemenag Provinsi Jawa Barat dengan memperhatikan tahapan-tahapan manajemen.

Tahap pertama, perencanaan. manajemen pelayanan yang diterapkan di Kanwil Kementerian Agama Provinsi Jawa Barat dimulai dari perencanaan penyusunan program-program pelayanan ibadah haji di Kanwil Kementerian Agama Provinsi Jawa Barat. Apa yang menjadi tugas dan fungsi Kementerian Agama disusun dan dirancang dalam bidang-bidang pelayanan mulai dari pendaftaran sampai pemulangan jemaah calon haji. Namun pada pelayanan pendaftaran jemaah haji yang dilakukan oleh domain kanwil hanyalah haji khusus, dan itupun bukan jemaah haji yang mendaftar, tapi diwakili oleh pihak travel yang menyelenggarakan ibadah haji khusus.

Perencanaan pelayanan yang dilakukan oleh Kementerian Agama Provinsi Jawa Barat antara lain: perencanaan pendaftaran, perencanaan pelunasan, perencanaan pembatalan, perencanaan pengelolaan dokumen perjalanan ibadah haji, perencanaan bimbingan manasik haji, perencanaan pembentukan karu dan karom, perencanaan pemberangkatan, dan perencanaan pemulangan. Perencanaan tersebut dilakukan dengan melihat peraturan perundang-undangan haji yang terbaru sesuai dengan intuksi Kementerian Agama republik Indonesia yang mengatur perihal penyelenggaraan ibadah haji tahun 2017.

Tahap kedua, pengorganisasian. Setelah bidang-bidang pelayanan yang telah terencanakan selanjutnya dilakukan pengorganisasian staf Kementerian Agama Provinsi Jawa Barat, pengorganisasian merupakan suatu kegiatan pengaturan sumberdaya manusia yang terdapat dalam suatu organisasi sesuai kemampuannya untuk menjalankan rencana yang telah ditetapkan dan menggapai tujuan organisasi. (Kusnawan, 2015)

Tahap ketiga, pelaksanaan pelayanan. Setelah dilakukan perencanaan dan pengorganisasian maka selanjunya pelaksanaan pelayanan. Pelayanan yang diberikan oleh Kanwil Kementerian Agama Provinsi Jawa Barat pada tahun 2017 antara lain: pelayanan pendaftaran / pelunasan, pelayanan pembatalan, pelayanan biaya penyelenggaraan ibadah haji, pelayanan dokumen-dokumen ibadah haji, pelayanan mutasi jemaah, pelayanan bimbingan manasik haji, pelayanan pembentukkan karu dan karom, pelayanan pemberangkatan, dan pelayanan pemulangan.

Dalam pencarian data, yang diproleh dari Kanwil Kemenag Jabar Bidang Haji dan Umrah, Amri sebagai staff bidang haji dan umrah menyatakan bahwa

"Pelayanan yang secara langsung diberikan kepada jemaah calon haji di

Kanwil Kementerian Agama Provinsi Jawa Barat adalah pelayanan pendaftaran untuk haji khusus, pelayanan pendaftaran untuk haji reguler oleh kemang kota atau kabupaten, pelayanan pelunasan, pelayanan mutasi, pelayanan pembatalan, pelayanan pemberangkatan, dan pelayanan pemulangan. Sedangkan pelayanan tidak langsung seperti pembayaran pendaftaran atau pelunasan biaya penyelenggara ibadah haji, pembuatan passpor, pelayanan kesehatan, dan pelayanan monitoring bimbingan 
manasik haji Kanwil Kementerian Agama Provinsi Jawa Barat berkoordinasi dengan kemenag kota atau kabupaten, lembaga pemerintah dan swata seperti dinas keimigrasian, dinas kesehatan, KUA masing- masing kecamatan, bank penerima setoran, dan kepolisian dalam rangka mensukseskan penyelenggaran ibadah haji tahun 2017'. (wawancara, 5 Februari 2018)

Amri juga mengungkapkan bahwa bentuk pelayanan yang diberikan, Kanwil Kementerian Agama Provinsi Jawa Barat memberikan bentuk pelayanan berupa pelayanan lisan, tulisan, dan perbuatan. (wawancara, 5 Februari 2018)

Pelayanan tulisan adalah pelayanan dengan melalui tulisan atau gambar sebagai pentunjuk pelayanan. Pelayanan tulisan terdiri atas dua golongan. Pertama, pelayanan berupa petunjuk, informasi dan yang sejenisnya diajukan kepada orang yang berkepentingan. Kedua, pelayanan berupa reaksi tertulis atas permohonan, laporan, keluhan, pemberian/penyerahan, dan pemberitahuan. Dilihat dari pelayanan tulisan yang diberikan oleh Kanwil Kementerian Agama Provinsi Jawa Barat, pelayanan tulisan berupa berupa petunjuk, informasi terrelisasikan dengan adanya tulisan dan banner pemberitahuan persyaratan dan prosedur pendaftaran, pembatalan, dan alur dalam melakukan pendaftaran maupun pembatalan yang terdapat di dalam maupun diluar ruangan Kanwil Kementerian Agama Provinsi Jawa Barat. Pelayanan berupa permohonan, pemberian/penyerahan dan pemberitahuan dilakukan dengan lembaga pemerintah yang mempunyai peran andil dalam penyelenggaraan ibadah haji di Provinsi Jawa Barat. Namun terkait pelayanan keluhan berupa tulisan belum terdapat dalam Kanwil Kementerian Agama sepeti kotak saran pelayanan, hal ini menjadi penting untuk mengetahui kekurangan ataupun kelebihan dari pelayanan yang diberikan dan dapat dijadikan sebagai salah satu bahan evaluasi dalam upaya meningkatkan kualitas pelayanan di Kanwil Kementerian Agama Provinsi Jawa Barat.

Pelayanan perbuatan merupakan pelayanan dengan melalui tindakan atas suatu pekerjaan. Pelayanan ini memerlukan faktor keahlian dan keterampilan petugas, karena akan sangat menentukan terhadap hasil perbuatan atau pekerjaan. Tujuan utamanya bagi pihak yang berkepentingan ialah mendapatkan pelayanan dalam bentuk perbuatan atau hasil perbuatan, bukan sekedar penjelasan dan kesanggupan secara lisan. Pelayanan perbuatan Kanwil Kementerian Agama Provinsi Jawa Barat dalam hal ini dapat terlihat pengoprasian sistem informasi dan komputerisasi haji terpadu baik dalam hal pendaftaran dan update data jemaah, pelayanan pembatalan jemaah calon haji, pelayanan mutasi jemaah calon haji, pelayanan penyusunan dokumen paspor dan visa haji, pelayanan pemberangkatan dan pelayanan pemulangan.

Tahap keempat, pengendalian. Pengendalian merupakan aktivitas menilai kinerja berdasarkan standar yang telah dibuat untuk kemudian dibuat perubahan atau perbaikan jika diperlukan. Amri (menyatakan bahwa proses pengawasan langsung dilakukan oleh Kasi PHU Kemenang Provinsi Jawa Barat kepada stafstafnya dengan melakukan interaksi dan melihat kinerja staf sesuai dengan tugas 
dan tanggung jawabnya. Pegawasan langsung juga dilakukan di KUA kecamatan dan KBIH dalam melaksanakan bimbingan manasik haji melalui perwakilan staff Kemenag Provinsi Jawa Barat. Sedangkan pengawasan tidak langsung yang diterapakan di Kanwil Kementerian Agama Provinsi Jawa Barat adalah dengan menerapkan laporan kinerja harian pada masing-masing staf Kemenang Provinsi Jawa Barat, laporan kinerja harian dikumpulkan dan ditanda tangani setiap 3 bulan sekali dan melakukan rapat evaluasi setiap 1 bulan sekali atau melakukan rapat terbatas insidenal ketika terjadi masalah dan diperlukan untuk menentukan alternatif penyelesaiaan masalahnya. wawancara 5 Februari 2018)

Bertolak dari berbagai problematika yang dialami oleh Kanwil Kementerian Agama Provinsi Jawa Barat, menurut Amri (wawancara 5 Februari 2018) memngungkapkan bahwa manajemen pelayanan jemaah calon haji dapat dikatakan baik karena penyelenggaraan ibadah haji dapat berjalan sukses dengan indikator. Seluruh jemaah calon haji Provinsi Jawa Barat yang terdaftar dan memenuhi syarat keberagkatan tahun 2017 dapat diberangkatkan ke Arab Saudi tanpa ada yang batal berangkat karena visa jemaah yang belum keluar. Seluruh jemaah calon haji Provinsi Jawa Barat yang telah berada di Arab Saudi, memperoleh layanan akomodasi, katering dan transportasi.

Proses pelayanan di Kanwil Kementerian Agama Provinsi Jawa Barat oleh staf Kanwil Kementerian Agama Provinsi Jawa Barat Bidang Penyelenggaraan Haji dan Umrah terdapat berbagai faktor pendukung dan faktor penghambat dalam melayani jemaah calon haji. Dalam teori manajemen, proses pelaksanaan kegiatan harus menggunakan dasar analisis yang pasti. Analisis yang peniliti uraikan adalah analisis SWOT.

Penerapan analisis SWOT tidak hanya pada bidang organiasasi dan bisnis tetapi juga pada sektor publik dan organisasi non profit, baik pada lingkup negara maupun regional. Analisis SWOT didasarkan pada logika yang dapat memaksimalkan kekuatan (strengths) dan peluang (opportunities), namun secara bersamaan dapat meminimalkan kelemahan (weaknesses) dan ancaman (threats). Ada dua faktor yang mempengaruhi pelayanan dalam ibadah haji, yaitu faktor internal dan faktor ekternal. Analisis SWOT mengidentifikasi faktor internal yaitu faktor yang sepenuhnya berada dalam kendali organisasi dalam hal ini berupa kekuatan dan kelemahan dalam organisasi. Sedangkan faktor ekternalnya adalah faktor yang tidak terkontrol oleh organisasi yang berasal dari luar yaitu berupa peluang dan ancaman. (Hasibuan, 2011: 35)

Dari hasil analisis Swot dapat disimpulkan faktor pendukung dan penghambat yang terdapat di Kanwil Kementerian Agama Provinsi Jawa Barat antara lain:

Pendukung: Sumber daya manusia yang berkualitas dan berpengalaman; Kepemilikan atas sarana dan prasarana dalam memberikan pelayanan kepada Jemaah; Sumber dana penyelenggaraan ibadah haji oleh pemerintah; Lingkungan masyarakat Provinsi Jawa Barat yang mendukung penuh aktivitas pelayanan penyelenggaraan ibadah haji; Hubungan kerjasama yang baik antar lembaga 
pemerintah dan swasta dalam rangka mensukseskan penyelenggaraan ibadah haji di kaupaten Provinsi Jawa Barat.

Penghambat: Perbedaan kemampuan dalam pengoprasian teknologi pada masing-masing staf menjadi salah satu kelemahan di Kanwil Kementerian Agama Provinsi Jawa Barat; Optimalisasi sarana dan prasarana perlu lakukan, melalui perbaikan maupun peremajaan sarana sebagai penunjang pelayanan; Perubahan regulasi ibadah haji yang sering berubah-ubah menyangkut proses pelayanan menjadi salah suatu kelemahan dalam mengimplementasikan regulasi tersebut, Pelaksanaan regulasi baru yang tidak diimbangi dengan sistem dan saranaprasarana yang kurang memadai menjadi hambatan yang serius dalam memberikan pelayanan kepada jemaah calon haji; Keragaman jemaah calon haji dilihat dari faktor usia, pendidikan, ekonomi, dan sosial yang berbeda-beda yang menimbulkan tingkat pemahaman yang berbeda-beda.

Suryati, menyatakan bahwa penyelenggara tahun ini sangat memuaskan, namun dari segi menu makanan yang disajikan tidak begitu bersahabat dengan lidah, mungkin sajian makanannya harus selalu sehat supaya kondisi badan kita selama disana terjaga. (wawancara 17 Februari 2018)

Dengan demikian jemaah haji ini menyatakan kepuasannya, walaupaun ada rasa ketidakpuasan dari segi menu makanan yang disajikan, namun disadari bahwa sajian makanan itu untuk menjaga kesehatan selama berada di tanah suci.

Jaringan Alumni Jemaah Haji, Untuk peningkatan kualitas alumni jemaah haji dapat didukung dengan adanya jaringan alumni dari jemah haji. Jaringan alumni akan sangat membantu dalam mengadakan kajian-kajian tentang haji setelah kepulangan dari tanah suci dan meningkatkap persaudaraan. Dengan adanya jaringan alumni, akan memberikan sumbangan pemikiran pada penyelenggaraan haji yang akan datang, terutama dalam hal bimbingan manasik haji yang dilakukan sebelum pemberangkatan ke tanah suci.

Sesuai dengan hasil wawancara yang diproleh dari staff Kanwil Kemenag Jabar, Amri mengungkapkan bahwa

"Untuk jaringan haji memang sudah ada, yaitu Ikatan Persaudaraan Alumni Haji Indonesia (IPHI), namun tidak ada pengawasan dan koordinasi secara khusus dengan pihak Kanwil Kemenag Jabar terkait dengan pengawasan. Karena sebetulnya dari penyelenggara Kanwil Kemenag Jabar sudah tidak bertanggung jawab apabila jemaah haji sudah dipulangkan ke rumahnya masing-masing". (wawancara 19 Februari 2018)

Terkait dengan ikatan persaudaraan alumni haji, Salmidin mengungkapkan setelah kepulangannya ada yang membertahukan bahwa alumni haji yang baru pulang akan diundang untuk melakukan perkumpulan alumni jemaah haji, namun sampai saat ini pemberitahuan itu belum ditindak lanjuti. Komunikasi dengan alumni haji yang lainnya dilakukan hanya sebatas dengan rekan alumni jemaah haji yang memang sebelumnya kenal, bukan karena forum atau jaringan alumni haji. (wawancara 17 Februari 2018)

Dengan demikian, sesuai dengan penjelasan staff Kanwil Kemenag Jawa 
Barat bidang haji dan umrah, bahwa alumni haji sudah terbentuk jaringan alumninya yaitu ikatan persaudaraan haji indonesia, namun pada praktisnya, tidak semua alumni jemaah haji tersentuh dengan forum alumni ini. Selain itu juga tidak ada pengawasan secara khusus kepada IPHI dari Kanwil Kemenag Jabar. Padahal semua pegawai dari mulai ketua bidang sampai dengan staff di Kanwil Kemenag Jabar merupakan alumni dari jemaah haji itu sendiri.

Tempat Pemberangkatan Jemaah Haji , Tempat yang dipakai untuk embarkasi haji adalah asrama haji Bekasi, Jalan Kemakmuran No.72, Marga Jaya, Bekasi Selatan, Marga Jaya, Bekasi Sel., Kota Bks, Jawa Barat.

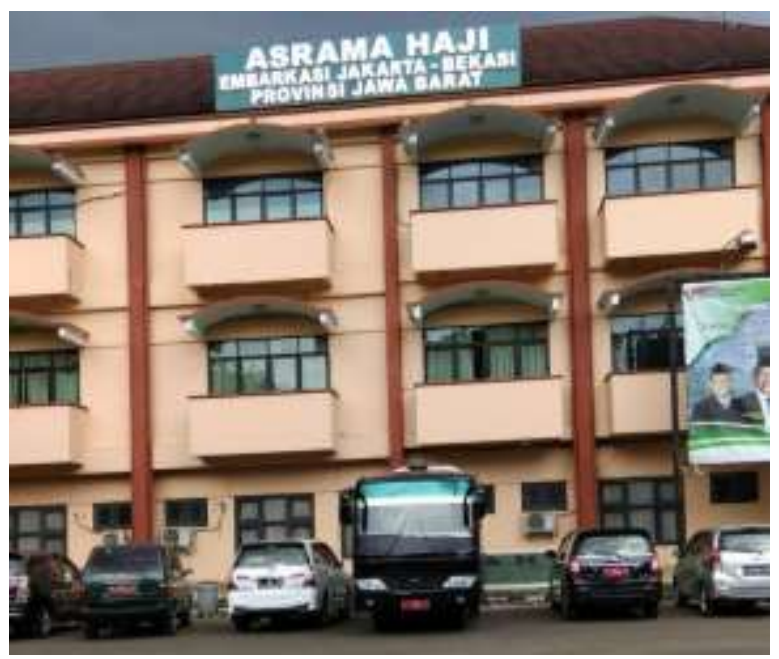

Gambar. 1 Asrama Haji Embarkasi Bekasi

Sumber: Dokumen Pribadi

Terkait dengan hal itu, Suryati (wawancara 17 Februari 2018), menyatakan bahwa mengenai tempat sangatlah memadai, semua jemaah tertampung dan tempat juga sangat terawat. Salmidin (wawancara 17 Februari 2018), berpendapat asrama haji sangat nyaman, naum wilayahnya tidak sejuk dan gersang, mungkin karena jumlah jemaah yang banyak dan juga daerah bekasi memang sangat panas. Namun tidak mengurangi kenyamanan pada saat berada di asrama haji.

Sebagai staff Kanwil Kemenag Jabar, Amri (wawancara 5 Februari 2018) mengungkapkan bahwa Provinsi Jawa Barat sangat berutung karena memiliki Asrama Haji yang tidak rebutan dengan jemaah haji provinsi lain. Karena sangat sedikit provinsi yang memiliki asrama hajinya sendiri. Asrama haji di seluruh Indonesia hanya ada 13 (tiga belas), kita bandingkan dengan jumlah seluruh provinsi yang ada di Indonesia yaitu 33 (tiga puluh tiga) dimana selihih jumlahnya sangat jauh. Maka Jawa Barat adalah salah satu provinsi yang memiliki asrama haji sendiri.

Dengan demikian, tempat pemberangkatan atau embarkasi haji sangatlah nyaman, terkait dengan suasana yang panas dan berdesak-desakan dengan jemaah yang lain itu adalah hal yang wajar, karena keberlangsungan di Embarkasi sendiri 
tidaklah memakan waktu yang lama. Dan mengingat asrama ini diperuntukan hanya untuk satu provinsi, jadi dalam praktisnya sangat nyaman karena tidak bercampur dengan provinsi lainnya.

Seperti yang di kemukakan di awal pemaparan bahwasanya Kanwil Kemenag Provinsi Jawa Barat bidang haji dan umrah merupakan penyelenggara ibadah haji. Artinya penyelenggara bertanggung jawab penuh untuk memberikan pelayanan pada pengguna jasa, dalam hal ini adalah jemaah haji. Bukan hanya pelayanan materi berupa kebutuhan individu seperti makan, pakaian dan peralatan lainnya, namun juga berupa pelayanan yang bersifat mendukung kenyamanan ibadah para jemaah haji. Pelayanan pada jemaah haji merupakan indikator mutu atau kualitas yang menentukan apakah kanwil kemenag jabar memiliki kualitas yang baik dalam pelayanan kepada jemaah sebagai pengguna jasa. Sehingga dengan memaksimalkan pelayanan itu, jemaah haji akan semakin mantap dalam beribadah, dengan begitu akan terbentuk alumni jemaah haji yang memiliki predikat mabrur dalam artian setelah kepulangannya dari melaksanakan ibadah haji, alumni jemaah haji memiliki peningkatan dalam hal ukhrowi dan juga peningkatan yang bersifat duniawi.

Dengan kata lain, melalui manajemen yang baik, kesalahan dalam organisasi bisa di minimalisir dan diantisipasi dari jauh-jauh hari. Dengan memperhatikan mutu, semua pekerjaan bisa dilakukan dengan maksimal dan memuaskan dari berbagai sudut. (Ishikawa 1992: 16)

Pelayanan dapat diartikan sebagai kepedulian kepada pelanggan-pelanggan dengan memberikan layanan terbaik untuk memfasilitasi kemudahan pemenuhan kebutuhan dan mewujudkan kepuasannya. Keberhasilan program Pelayanan tergantung pada penyelarasan kemampuan, sikap, penampilan, perhatian, tindakan, dan tanggung jawab dalam pelaksanaannya. (Rianto Al Arif 2010:214)

\section{Mutu Kemabruran Ibadah Haji di Kanwil Kementerian Agama Provinsi Jawa Barat}

Haji mabrur secara garis besar berati diterimanya amal ibadah seseoarang ketika melaksanakan haji. Ibadah haji merupakan ibadah mutlak, yang nantinya seseorang akan mendapat balasan surga.

Haji mabrur yang dimaksud di sini adalah apabila seseorang tersebut melaksanakan perintah Allah SWT secara keseluruhan dengan penuh ketulusan sesuai dengan perintah syari'at Islam ketika hendak melaksanakan ibadah haji. (Madjid, 1997:28)

Sebenarnya sekian para ulama' tidak memberikan definisi haji mabrur secara tafsili, namun mereka (para fuqoha) hanya memberikan petunjuk indikasi-indikasi tertentu tentang seseorang setelah melaksanakan ibadah haji, indikasi tersebut dapat diidentifikasi melalui adanya perubahan-perubahan positif pada perbuatan seseorang, oleh karenanya masyarakat kota Pasuruan yang memegang tradisi para leluhurnya melakukan ritual berdiam diri selama 40 hari yang dimaksudkan untuk merenungkan perbuatan-perbuatannya sebelum haji yang dianggap tidak selaras dengan aturan- aturan syari'at Islam. Berikut adalah 
kutipan wawancra yang dilakukan dengan salah satu tokoh masyarakat Kp. Cimanggu Hilir yang bernama Hamdan (wawancara 5 Februari 2018), dimana sebagai berikut:

"Haji mabrur itu adalah ibadah haji yang diterima di sisi Allah, maksudnya apa? Yaitu orang yang melakukan ibadah haji dengan ikhlas menurut syari'at Islam, seperti ikhlas dalam rukun, syarat serta semua kegiatankegiatan haji (manasik haji) sampai dia pulang dari tanah suci makkah, sehingga adatnya orang Pasuruan setelah pulang dari haji, mereka berdiam diri dengan merenungkan kesalahan-kesalahan yang dilakukan sebelumnya, dan tidak itu saja, ada juga yang melakukan kegiatan-kegiatan (dalam berdiam diri tersebut) dengan mendo'akan orang-orang yang menjenguknya, hal ini dimaksudkan karena orang yang berhaji dianggap mustajab do'anya"

Statement yang memiliki subtansi yang sama, telah dilontarkan juga oleh Salmidin, dimana beliau pribadi merasakan hal-hal baru dalam hidupnya pasca melaksanakan haji, dimana sebagai berikut:

“Para ulama' terdahulu memang tidak memberikan pengertian haji mabrur secara gamblang, karena hal ini hanya dapat dicerna melalui rasa, dan hanya orang yang pernah melaksanakan ibadah haji yang pernah merasakannya, seperti saya pribadi yang dulunya sebelun melakukan ibadah haji dikenal sebagai orang yang benar tingkah lakunya, riil dulu sering kali saya melanggar larangan-larangn agama, seperti keberanian memakan makanan haram, dan saya akui itu, namun setelah menunaikan haji, dalam diri saya pribadi muncul perubahan-perubahan positif, dimana ketika dihadapkan dengan hal-hal yang haram dilakukan, serentak muncul dialog pribadi antara hati dan pikiran untuk memahami serta menimbang tentang sesuatu yang saya hadapi tersebut, dari sini saya sadar bahwa munculnya perubahan-perubahan positif pada pribadi saya setelah menunaikan ibadah haji”. (wawancara 17 Februari 2018)

Salmidin (wawancara 17 Februari 2018), yang mempunyai latar belakang dari orang minim akan wawasan agama, sehingga apa yang dilakukan dalam kehidupan sehari-harinya khusunya perihal tentang aturan syari'at islam, beliau landasi dengan dasar pengalaman-pengalaman pribadi tentang spiritualitas yang dilakukannya. Kemudian beliau meneruskan dengan memberikan arti haji mabrur:

"Setelah saya sadari adanya perubahan-perubahan postiif pada pribadi saya, serentak saya ceritakan pada tokoh agama Kp. Cimanggu Hilir yang bernama Ustadz Nazmu, lantas tokoh agama tersebut menjawab yang intinya: ibadah haji itu sulit dilakukan, sehingga teramat jarang ibadah haji seseorang dapat diterima disisinya, dan kita tidak dapat mengganggap haji seseorang itu diterima dengan tidaknya, hanya Allah semata yang maha mengetahui akan hal itu, hanya saja diterimanya haji seseorang dapat dirasakan dari adanya bentuk perubahan-perubahan positif dalam 
kehidupan sehari-harinya ketimbang dengan masa lalunya, ustadz Nazmu menyarankan saya untuk menjaga kesucian dengan berdiam diri untuk beribadah dan menjaga kesucian dari perbuatan dosa seperti apa yang telah dilakukan oleh ulama' terdahulu"

Dari paparan serta penjelasan diatas, dapat dikatakan bahwa setelah melaksanakan ibadah haji, jemaah mengakui ada yang berubah pada dirinya. Perubahan itu menuju pada arah yang lebih baik dan jemaah lebih berhati-hati untuk bersikap dalam rangka menjaga kesucian ibadah hajinya.

Sebuah potret haji mabrur tidak hanya dinilai pada saat proses ibadah haji tersebut berlangsung, tapi, juga dinilai setelah ibadah haji berakhir. Ada semacam indikator ke-mabrur-an haji yang tampak pada sikap-sikap tertentu setelah pulang ketanah air, seperti patuh melaksanakan apa-apa yang diperintahkan oleh Allah SW'T, patuh melaksanakan sholat, konsekuen membayar zakat, sungguh-sungguh membangun keluarga sakinah mawaddah warahmah, selalu rukun pada sesama umat manusia, sayang pada setiap makhluk Allah SWT, ia juga konsekuen meninggalkan apa-apa yang dilarang oleh Allah SW'T., terutama dosa-dosa besar, seperti syirik, riba, judi, zina, khamr, korupsi, membunuh orang, bertengkar, menyakiti orang lain, kufarat, bid'ah, dan lain-lain. (Farid, 1997: 209).

Mabrur juga berarti menjadi haji yang mendapatkan birr-un (kebaikan) dan sering juga diartikan sebagai ibadah haji yang diterima Allah SWT, dengan kata lain mabrur adalah haji yang mendapatkan kebaikan atau haji yang pelakunya menjadi baik (Madjid, 1997: 65)

\section{Dampak Alumni Jemaah Haji di Tengah Masyarakat Setelah Melaksanakan Ibadah Haji}

Ibadah haji memilki banyak manfaat. Selama ini ibadah haji hanya di nilai memilki manfaat secara ukhrawi saja. Padahal tidak demikian baik secara duniawi maupun ukhrawi ibadah haji memiliki manfaat yang besar. (Cholish. 1997:23)

Manfaat duniawi yang dimaksud di sini berkaitan dengan banyak aspek, tetapi pada akhirnya mengantar umat manusia meraih kemajuan dan kemaslahat bersama. Apa lagi Allah tidak melarang melakukan kegiatan ekonomi pada musim haji.

Dampak duniawi, dalam bidang ekonomi ibadah haji dari segi ekonomi memberikan kesempatan bagi kaum muslimin untuk mengembangkan usaha dan meningkatkan hubungnan ekonomi antarar sesamanya dalam forum yang lebih luas, forum internasional.

Berdasarkan hasil penelusuran yang didapatkan dari salah seorang masyarakat yang tempat tinggalnya jauh dari kediaman jemaah haji, yaitu Agus mengungkapkan bahwa

"Ibadah haji juga mampu memberikan manfaat secara ekonomi di Negaranegara lain. Hal ini dapat dilihat disaat musim haji tiba. Berapa banyak $\mathrm{KBIH}$ dan agent trevel yang memberangkatkan calon jamaah haji ke tanah makkah. Berapa banyak keuntungan yang didapat dari jamaah haji dengan system pemberangkatan yang ditetapkan saat ini. Hal ini tanpa disadari telah 
memberikan keuntungan ekonomi yang luar biasa besarnya." (wawancara 17 Februari 2018)

Agus juga meyatakan bahwa alumni haji pada tahun ini memiliki manfaat secara duniawi dalam perekonomian, terbukti salah satu jemaah haji di wilayah ini melakukan budidaya ikan di tanah yang dimilikinya, lalu setelah ikan itu dipanen masyarakat sekitar merasakan hasil dari budidaya ikan tersebut. Selain ikan itu dijual pada masyarkat, ikan itu juga dibagikan ke tetangga terdekat untuk dinikmati. (wawancara 17 Februari 2018)

Meningkatkan Budaya dan Mental, Ibadah haji dapat menambah luasnya wawasan dan pengalaman seorang muslim, disamping mengantarkan dirinya ke tengah dunia pergaulan yang lebih luas ketimbang lingkungannya selama ini.

Dalam perjalanan haji, orang akan diuji dengan berbagai kesulitan berpisah dengan keluarga dan kampung halaman, dan mengorbankan segala kesenangan serta kegiatan-kegiatan rutin di tengah-tengah keluarga. Dan amat bijaksana, Allah tidak menetapkan perjalanan haji ini ke kota seperti Switzerland, atau Libanon atau lainnya, atau lainnya dari kota-kota indah yang biasa ramai dikunjungi orang, untuk berlibur musim panas atau musim dingin. Tapi, justru Allah menghendaki perjalanan haji ini ke lembah yang gersang dan tanpa tanaman dan tetumbuhan, yang tidak bisa untuk berlibur musim panas dan juga musim dingin. (Cholish. 1997 :23)

Agus juga mengungkapkan tentang bagaimana alumni haji bercerita tentang pengalamnnya selama berada di sana

"Alumni haji ini selalu bercerita tentang pengalamannya selama di sana, dan tentu saja budaya baru yang diceritakan menambah wawasan juga kepada masyarakat sekitar yang selalu penasaran dengan hal baru, dengan demikian selain jemaah haji mendapatkan pengalalman dan budaya baru, masyarakat sekitarpun merasakan budaya baru itu dikehdupannya karena telah mendengar pengalaman baru yang dikisahkan melalui alumni haji itu". (wawancara, 17 Februari 2018)

Persatuan dan Perdamaian, Dalam ibadah haji, kita juga menjumpai nilainilai persatuan yang amat gamblang. Mereka para hujjaj satu dalam persatuan, satu dalam penuanaian kewajiban, dan satu dalam tujuan,satu dalam gerak amalan, dan satu pula dalam ucapan. Bukan karena kedaerahan dan unsur-unsur keduniaan. Bukan pula karena fanatik kebangsaan, keturunan atau tingkat kedudukan. Tapi hanya karena mereka semuanya orang muslim, yang beriman kepada Tuhan yang satu Allah SWT, berthawaf di rumah yang satu Bait Al-haram, berpedoman pada kitab yang satu Al-qur'an, berpanutan kepada Rasul yang satu Muhammad SAW, dan menunaikan amalan-amalan yang satu yaitu ibadah haji. Seluruh hal tersebut sudah melambangkan bahwa ibadah haji dapat memberi nilai persatuan pada seluruh umat Islam.

Sementara itu, ibadah haji merupakan salah satu wahana efektif bagi kaum muslimin dalam mewujudkan perdamaian. Karena perjalanan ibadah haji merupakan perjalanan yang perdamaian, menuju ke tanah perdamaian dan berada 
pada bulan-bulan perdamaian.adalah daerah terhormat, Baitul Haram yang telah dijadikan oleh Allah sebagai suatu kawasan tempat tinggal yang penuh keamanan. (Madjid, 1997: 25)

Agus juga berpendapat tentang dampak yang diberikan oleh jemaah haji kepada masyarakat sekitar bahwa

"Alumni haji ini mampu membawa energi positif dalam mempersatukan umat disekitar wilayahnya, karena lebih disegani dari orang lain yang memang belum berhaji. Dalam persatuan umat, alumni haji ini kerap hadir dalam berbagai kegiatan musyawarah dan pengajian rutinan dan juga beliau selalu mengajak masyarakat sekitar untuk melakukan kegiatan yang baik secara berjamaah". (wawancara 17 Februari 2018)

Dampak Ukhrawi, pengaruh pada jiwa dan kehidupan tujuan pertama dari peribadatan dalam islam adalah mengikuti printah-perintah Allah dan memenuhi hak-hak-Nya, namun sementara itu kita tidak mengingkari bahwa dibalik peribadatan-peribadatan tersebut terdapat pengaruh-pengaruh positif dan manfaat-manfaat yang amat besar bagi kehidupan pribadi dan jamaah. Agus (wawancara 17 Februari 2018), menyatakan bahwa,

"Alumni haji ini mampu memberikan contoh perilaku baiknya dalam beribadah kepada Allah SW'T. Sehingga berdampak pada jamaah lain untuk mengikuti jejak langkahnya. Sehingga masyarakat sekitar merasa iri untuk mengikuti keistiqomahannya dalam beribadah kepada Allah SW'T".

Menyuburkan Rohani, Ibadah haji menyuburkan kekuatan rohani, yang merupakan bekal amat penting bagi kehidupan seorang muslim. Karena denga ibadah haji, hati semakin bergairah dalam mentaati perintah-Nya dan semakin menyesal atas mendurhakai-Nya. Perasaan cinta kepada Allah pun semakin mendalam, demikian pula terhadap Rasul-Nya, para pengikut dan pendukungnya, dan terhadap semua orang yang bersedia mengikuti cahaya kebenaran yag diajarkan olehnya. Dengan demikian perasaan ukhuwah terhadap sesama muslim di mana saja berada akan tetap menyala, semangat membela dan mempertahankan islam pun semakin membara.

Agus memberikan ungkapkan tentang jemaah haji setelah kepulangannya dari tanah suci.

"Alumni haji ini selalu menjaga perkataan dan sikapnya dengan sangat baik,

karena beliau khawatir akan merusak ibadah hajinya. Dan sikap baik itu menjadikan hal yang positif karena secara tidak langsung sudah menyebar luas kepada masyarakat lain yang belum pernah melaksanakan ibadah haji”. (wawancara 17 Februari 2018)

Outcome Maping fokus pada hasil yang sangat spesifik: perubahan prilaku, hubungan, kegiatan, atau tindakan orang-orang, kelompok dan organisasi yang bekerja langsung dalam program. Prubahan prilaku memiliki kontribusi yang sangat penting dalam pencapaian tujuan akhir program. (Deprez, 2010: 1-2)

Orang yang hajinya mabrur dapat terlihat setelah pulang haji menjadi gemar melaksanakan ibadah-ibadah sunnah dan amal saleh lainnya serta berusaha 
meninggalkan perbuatan-perbuatan yang makruh dan tidak bermanfaat, ia pun aktif berkiprah dalam memperjuangkan, mendakwakan Islam dan istiqomah serta sungguh-sungguh dalam melaksanakan amar ma'ruf dengan cara yang ma'ruf, melaksanakan nahi munkar tidak dengan cara yang munkar, sifat dan sikapnya berubah menjadi terpuji seperti sabar, syukur, tawakkal, tasamuh, pemaaf, tawadhu, dan lain-lain. (Madjid, 1997: 35)

\section{PENUTUP}

Temuan penelitian penyelenggaraan ibadah haji di Kanwil Kemenag Provinsi Jawa Barat adalah : Kanwil Kemenag Jabar sebagai leading sector penyelenggara ibadah haji. Kanwil Kemanag Jabar Bidang haji dan Umrah sangat bertanggung jawab atas penyelenggaraan ibadah haji. Dalam meraih kesuskesannya dalam menyelenggarakan ibadah haji, Kanwil Kemenag Jabar memperhatikan tahapantahapan, diantaranya: a) Perencanaan; b) Melakukan pengorganisasian, yaitu pengaturan sumberdaya manusia yang dimiliki oleh Kanwil Kemenag jabar; c) Pelaksanaan pelayanan pada jemaah haji; d) Pengendalian merupakan aktivitas menilai kinerja berdasarkan standar yang telah dibuat untuk kemudian dibuat perubahan atau perbaikan jika diperlukan.

Mutu kemabruran jemaah haji didasarkan pada perubahan sikap jemaah haji yang lebih baik. Ada beberapa indikator yang ditunjukan oleh jemaah terkait dengan kemabrurannya, yaitu perubahan menuju pada arah yang lebih baik dan jemaah lebih berhati-hati untuk bersikap dalam rangka menjaga kesucian ibadah hajinya.

Dampak alumni haji ditengah masyarkat memiliki dua sudut pandang, yaitu: yaitu: a) Duniawi berdasarkan hubungan langsung manusia, seperti jemaah haji ini selalu berbagi hasil panen ikannya dengan tetangga, membawa cerita yang baru dia dapatkan untuk membangkitkan semangat keislaman masyarakat sekitar, dan selalu memberikan contoh dan teladan yang baik bagi masyarakat. Karena jemaah haji ini lebih disegani setelah kepulangannya, maka ajakan dan seruan dalam kebaikan lebih diperhatikan oleh masyarakat sekitar; b) Ukhrowi berdasarkan hubungan dengan Allah SWT. Seperti peningkatan ibadah kepada Allah, baik ibadah yang wajib seperti shalat 5 waktu tepat waktu dan berjamaah dan ibadah sunnah seperti memperbanyak dzikir dan shalat sunnah.

Temuan penelitian manajemen mutu outcome penyelenggaraan ibadah haji di Kanwil Kemenag Provinsi Jawa Barat menyarankan sebagai berikut:

Bagi Penyelenggara, Penyelenggara dan juga pemerintahan untuk selalu memberikan pemahaman kepada masyarakat perihal tentang bagaimana menjalani hidup baik yang berkenaan dengan ibadah haji serta dalam menjalankan tugas-tugas keseharian sebagai anggota; Kanwil Kemenag Jabar memberikan pengawasan khusus dan menjalin kerjasama kepada IPHI (Ikatan Persaudaraan Haji Indonesia), supaya lebih efektif dalam mencipatakan ikatan persaudaraan antar jemaah haji; Mempertahankan hubungan yang harmonis dan meningkatkan kualitas pada karyawan sehingga terciptanya kerjasama yang baik 
dan pelayanan yang memuskan terhadap jemaah haji; Kanwil Kemenag Jabar Bidang Haji dan Umrah harus lebih maksimal dalam merespon keinginan jama'ah dalam setiap pelayanan yang diberikan.

Bagi Alumni Jemaah Haji, Alumni Jemaah haji, salah satu kelemahan alumni jemaah haji Indonesia khususnya Wilayah Provinsi Jawa Barat adalah kurangnya kesadaran akan pentingnya sebuah pendidikan agama, sehingga muncul masyarakat lemah kreatifitas, daya pikir, kurang inovatif dan juga lemah dalam memahami kondisi sosial dari zaman ke zaman, hal ini terbukti dengan adanya fakta bahwa alumnu jemaah haji beribadah tanpa tahu dasar hukum dan keilmuannya.

\section{DAFTAR PUSTAKA}

Choliq, A. (2011). Manajemen Haji dan Wisata Religi. Yogyakarta: Mitra Cendika.

Deprez Steff dkk. (2010). Outcome mapping. Denpasar: PT. Cintya

Farid, M. (1997). Antar Aku Ketanah Suci: Panduan Haji, Umrah, Ziarah. Jakarta: PT Gema Insani.

Nawawi, H. (2005). Manajemen Strategik. Yogyakarta: Gadjah Mada Pers

Hasibuan, M. S. (2011). Manajemen Dasar, Pengertian, dan Masalah. Jakarta: Bumi Aksara.

Ishikawa, K. (1992). Pengendalian Mutu Terpadu, PT Remaja Rosdakarya, Bandung. Kusnawan, A. (2015). Konsep Manajemen Pelatihan Dakwah. Ilmu Dakwah: Academic Journal For Homiletic Studies, 4(12), 335-370.

Madjid, N. C. (1997). Perjalanan Religius Umrah Dan Haji. Jakarta: PT Temprint.

Safroni, L. (2012). Manajemen dan Reformasi Pelayanan Publik dalam Konteks Birokrasi Indonesia. Surabaya : Aditya Media Publishing 